\title{
HasanuddinLawReview
}

Volume 4 Issue 1, April 2018

P-ISSN: 2442-9880, E-ISSN: 2442-9899

Nationally Accredited Journal, Decree No. 32a/E/KPT/2017.

This work is available at: Microsoft Academic Search.

\section{Khul'i (Right of Redemption) under Sharia Courts Rules of Bauchi State, Nigeria, 2013: Issues and Challenges}

\author{
Ibrahim Danjuma1, Umar Sulaiman Abbo Jimeta ${ }^{2}$ \\ ${ }^{1}$ Faculty of Law, Bauchi State University Gadau, Nigeria. E-mail: idanjuma27@gmail.com \\ 2 Faculty of Law, University of Maiduguri, Borno State, Nigeria. E-mail: jimetaabbo@gmail.com
}

\section{ARTICLE INFO}

Keywords:

Khul'i; Right of

Redemption; Muslims'

Countries; Nigeria; Sharia

Courts; Quantum

How to cite:

Danjuma, I., and Jimeta,

U.S.A. (2018). Khul'i

(Right of Redemption)

under Sharia Courts Rules

of Bauchi State, Nigeria,

2013: Issues and

Challenges. Hasanuddin

Law Review, 4(1): 30-40

DOI:

10.20956/halrev.v4i1.1415

\begin{abstract}
In the year 2000, most of the States in Northern Nigeria re-introduced Sharia as part of their legal system in disposing of both civil and criminal cases. Bauchi State was among the States that re-introduced Sharia as part of its legal system. Based on that, Sharia Courts were created to replace Area Courts, and Sharia Courts Civil Procedure Rules was enacted to regulate the proceedings before the said Sharia Courts on Civil Matters. The Bauchi State Sharia Courts Civil Procedure Rules, 2001 did not contain a provision on Khul'i. Prior to the amendment of Bauchi State Sharia Courts Civil Procedure Rules, Judges of Sharia Courts were in a serious dilemma as to the amount of money to be paid by a woman in order to relieve herself from the bond of marriage. This is because Khul'i is a right accorded to a wife to remove herself from the union of marriage (to get a divorce) by compensating her husband. In order to address the above problem and others, Sharia Courts Civil Procedure Rules of Bauchi State, 2001 was amended in 2013 and right of Khul'i (Redemption) was incorporated under Order 21 of the Bauchi State Civil Procedure Rules, 2013. With the amendment of the said Sharia Courts Civil Procedure Rules of Bauchi State, instead of addressing the problem of a quantum formula for Khul'i, rather brought a controversy to the said issue. Therefore, this study critically examines the Qur'anic Verses, Hadith and the opinion of the Islamic Scholars on Khul'i and compare them with Order 21 Right of Redemption (Khul'i) of Sharia Courts Civil Procedure (Amendment) Rules of Bauchi State, 2013 so as to ascertain its consistency or otherwise.
\end{abstract}

Copyright (C) 2018 HALREV. All rights reserved.

\section{Introduction}

Khul'i (right of redemption) is a right accorded to a wife to get a divorce from her husband from the bond of marriage either by initiating a divorce proceeding in a court or by a mutual consent of both parties and their representatives. There are divergent views among the Islamic Scholars regarding the quantum or amount to pay by a wife to her husband either in kind or cash. Most of the Muslims' countries like Pakistan, Libya, 
Iraq, Egypt, and Malaysia to mention a few have laws in their domestic legislation regulating the application of Khul'i.

Nigeria is one of the densely populated countries in Africa, with over 150 million citizens according to the 2006 National Population Census. It is a linguistically, religiously and culturally heterogeneous country. ${ }^{1}$ Prior to the advent of colonial administration in Nigeria, Islamic law in its entire ramifications was applied in what became Northern Nigeria $^{2}$ and the purpose was to form a society whose activities and organization would be molded in harmony with the Qur'an and Hadith. ${ }^{3}$ The spread of Islam started in Northern Nigeria as a result of contacts with traders from North Africa, and also, the Algerian Islamic scholar and a reformer Abd al-Karim Al-Maghili has played a vital role towards the spread of Islam before the end of the $15^{\text {th }}$ century. 4 The establishment of Sokoto Caliphate in the 19th century recorded a wide spread of Islam not only in Northern Nigeria but to the whole West Africa through the Jihad led by Sheik Usman Dan Fodio. ${ }^{5}$

As the result of a well-structured system of governance established by Sheik Usman Dan Fodio, the colonial administration did not temper with the said structure and allowed Muslims to practice their religion. ${ }^{6}$ The experience had by the British in Egypt and India in attempting to interfere with the practice of the Islamic religion compelled them to maintain such neutrality in Nigeria by avoiding confrontation with Islam. ${ }^{7}$ As such, Islamic law was applied but with some certain modifications. British colonial masters enacted Native Court Ordinances and Promulgations that regulated the application of Islamic law, the appointment, promotion and discipline of Alkalis (judges) by the Emir but subject to the approval of Resident or District Commissioner. ${ }^{8}$

The judicial system in Northern Nigeria from 1950 to 1960 was characterized by a dual system, i.e. British common law and Islamic law based on Maliki School of thought were duly applied. ${ }^{9}$ The British restricted the application of Islamic law to issues on family (custody, maintenance, marriage) and inheritance while criminal offences with capital punishments were not applied. ${ }^{10}$ After the independence of Nigeria in 1960, Islamic scholars and leaders on several occasions have demanded for a full application of Islamic law to go beyond the borders of personal law but proves abortive.

During the 1999 general elections after a long period of Military rule in Nigeria, the issue of Sharia re-implementation in most parts of Northern States of Nigeria was part of the campaign promises of some politicians in the said region. One of such politicians was Senator Ahmed Sani which during his campaign in Zamfara State, Nigeria, promised to

\footnotetext{
1 Amara, R.B. (2011). The Izala Movement in Nigeria: It's Spilt, Relationship to Sufis and Perception of Shari'a Re-Implementation. PhD Thesis, Bayreuth International Graduate School of African Studies, p. 71.

2 The present $S t a t e s$ that were carved out from the then Northern Region of Nigeria are Adamawa, Bauchi, Benue, Borno, Gombe, Jigawa, Kaduna, Kano, Katsina, Kebbi, Kogi, Kwara, Nassarawa, Niger, Plateau, Sokoto, Taraba, Yobe, Zamfara, and the Federal Capital Territory, Abuja.

3 Abikan, A.Q.I. (2002). "The Application of Islamic Law in Civil Causes in Nigerian Courts," Journal of International and Comparative Law, 6, pp. 88-115.

Amara, R.B. (2011). Op.Cit., pp. 71-74.

Ibid., p. 72.

Jonathan, R. (2001). "Good and Bad Muslims: Islam and Indirect Rule in the Northern Nigeria," International Journal of African Historical Studies, 3(4), pp. 601-618, p. 601.

Amara, R.B. (2011). Op.Cit., p. 86.

Abikan, A.Q.I. (2002). Op.Cit., p. 89.

Amara, R.B. (2011). Op.Cit., p. 90.

10 Amara, R.B. (2011). Op.Cit., p. 91.
} 
the good people of Zamfara State that if voted into power will re-introduce Islamic law, and safeguard Islam and Islamic principles. ${ }^{11}$

On the 27th day of October, 1999, Ahmed Sani the Governor of Zamfara State (as he then was) announced that it is high time to wake up from the state of slumber and have their affairs to be regulated by the Islamic injunctions in order to avoid the curse of Allah. ${ }^{12}$ After the official announcement of the Sharia re-implementation in Zamfara State, Sharia Courts, Sharia Penal Code Law, Sharia Court Criminal Procedure Code and Law on duties of Hisbah were enacted in accordance with the Islamic law.

Sequel to Sharia re-implementation in Zamfara State, most of the States in the Northern Nigeria re-introduced Sharia as part of their legal system in disposing of both civil and criminal cases. Bauchi State was among the States that re-introduced Sharia as part of its legal system. Based on that, Sharia Courts were created to replace Area Courts, and Sharia Courts Civil Procedure Rules was enacted to regulate the proceedings before the said Sharia Courts on Civil Matters. The Bauchi State Sharia Courts Civil Procedure Rules, 2001 did not contain a provision on Khul'i. Prior to the amendment of Bauchi State Sharia Courts Civil Procedure Rules, 2001, the Judges of the Sharia Courts were in a serious dilemma as to the amount of money to be paid by a woman as a consideration in order to relieve herself from the bond of marriage and to get a divorce from her Husband. This is because Khul'i is a right accorded to a wife to remove herself from the union of marriage by compensating her husband.

In order to address the above problem and others, the Sharia Courts Civil Procedure Rules of Bauchi State, 2001 was amended in 2013. Thus, the right of Khul'i (Redemption) was introduced under Order 21 of the Bauchi State Shari' a Courts Civil Procedure Rules, 2013 (hereinafter referred to as New Shari'a Courts Rules, 2013). Sequel to the amendment of the said New Shari'a Courts Rules 2013, instead of addressing the problem of a quantum of compensation for Khul'i, it brought controversy on the said issue.

Therefore, this study critically examines the Qur'anic verses, Hadith and the opinion of the Islamic Scholars on Khul'i and compare them with Order 21 Right of Redemption (Khul'i) of Sharia Courts New Rules, 2013 so as to ascertain its consistency or otherwise. It is hoped that the findings of this study will be useful in addressing the problem of quantum of compensating for a husband to release his wife from the bond of a marriage and other issues. Thus, the study begins with the discussion on the meaning and nature of Khul'i; thereafter, examines the laws and practices of Khul'i in selected Muslims' countries. The study further analyses the provision of Order 21 Right of Redemption (Khul'i) of Sharia Courts New Rules, 2013 and identifies the issues and challenges related to the said Order, and finally proffers some recommendations.

\section{The Meaning and the Nature of Khul'i under Islamic Law}

$K h u l^{\prime} i$ is derived from the Arabic word Khul'i al Thaub meaning releasing or removing a cloth from the body, due to the fact a woman is regarded as a cloth or dress to a man as stated in the holy Qur'an.13 The Holy Qur'an 2:182 provides that "the women are your dress and you are their dress".

\footnotetext{
$11 \quad$ Ibid., p. 295.

12 Oduyoye. M. (2000). The Sharia Debate in Nigeria: October 1999- October 2000. Ibadan, p. 1.

13 Doi, A.R.I. (1997). Sharia the Islamic Law. London: Ta Ha Publishers, p.192.
} 
The Islamic jurists give different definitions of Khul'i. Imam Malik is of the view that $K h u l^{\prime} i$ is a divorce by given something in return. Similarly, Imam Shafi'i defines it as a separation sought with something in return and with the pronouncement of the word Khul'i or divorce. ${ }^{14}$ While Imam Hannafi defines Khul'i as the termination of the contractual relationship between the spouses with the utterance of the word Khul'i or something similar to it. ${ }^{15}$ Imam Hanbal is of the view that, Khul'i is a separation of the husband in lieu of some consideration realized by him. ${ }^{16}$

Khul' $i$ refers to circumstances where a wife initiates the divorce proceeding and it in form of a recompense given to a husband by his wife who requests for separation or divorce. ${ }^{17}$ As soon as the husband accepts to divorce, his wife will return some money or dowry, the divorce is known as Talaq.

Divorce by Khul'i is made by means of proper words spoken or written by the couples or their representatives on the understanding that the wife offers a compensation to the husband in order to release her from the marital rights. ${ }^{18}$ That is, it means compromise by a husband his marital rights over his wife for an exchange from her a compensation either in kind or cash to release her from the bond of marriage. 19

In the wordings of Abdu, the unwillingness of a wife to perform or fulfil her conjugal duties, wishes to be divorced from the bond of marriage by her husband, she can do so by forfeiting her dowry if unpaid or recompense her husband with the dowry or property if the dowry was paid and such is called Khul'i.20

In a nut shell, Khul'i means a separation of the couples from the bond of marriage upon the payment of money or refund either in kind or cash by the wife which may be equivalent to the dowry or more or lesser than the dowry. The basic principle concerning Khul' $i$ is justified in the following verse of the Holy Qur'an, in which Allah says:

"And it is not lawful for you (men) to take back (from your wives) any of your Mahr (dowry given by the husband to his wife at the time of marriage) which you have given them, except when both parties fear that they would be unable to keep the limits ordained by Allah. Then if you fear that they would not be able to keep the limits ordained by Allah, then there is no sin on either of them if she gives back (the Mahr or a part of it) for her Al-Khul'i (divorce)"21

It is not a contested fact that during the lifetime of the Holy Prophet Muhammad (S.A.W), He ordered a wife to pay her husband what the husband gave her as a dowry. This is reported in the following hadith:

The wife of Thaabit ibn Qays ibn Shammaas (may Allaah be pleased with him) came to the Prophet (peace and blessings of Allaah be upon him) and said, "O Messenger of Allaah, I do not find any fault with Thaabit ibn Qays in his character or his religious commitment, but I do not want to commit any act of kufr after becoming a Muslim."

14 Ibid.

15 Ibid.

16 Ibrahim, A. (1972). Islamic Law in Malaya. Singapore: Malaysian Sociological Research Institute Ltd, p. 220.

17 Ciroma, A. (2009). Al-Khul': The Woman's Choice. Available online at http://al-amin-ciroma.blogspot.my/2009 /10/al-khul-womans-choice.html accessed November 6, 2015.

18 Ibrahim, A. (1972). Op.Cit., p. 210.

19 Ajijola, A.A.D. (1989). Introduction to Islamic Law. New Delhi: International Islamic Publishers, p. 171.

20 Abdu M. O. A. (1978). Islam as a Religion (Faith and Duties). Nigeria: Islamic Publications Bureau, Lagos, p. 43.

21 QS. Al-Baqarah 2:229 
The Prophet (peace and blessings of Allaah be upon him) said to her, "Will you give back his garden?" Because he had given her a garden as her mahr. She said, "Yes." The Prophet (peace and blessings of Allaah be upon him) said to Thaabit: "Take back your garden, and divorce her." 22

The duration of the waiting period (Iddah) of a divorce by way of Khul'i is as same as the ordinary divorce (talaq) by the husband i.e. three (3) menstrual courses, it is count as a single divorce but however, the husband cannot taker the wife back without her consent and a fresh marriage. ${ }^{23}$ For a Khul' $i$ to be valid in the eyes of the Islamic law, it must be made freely by the spouses, once it is shown that there is an element of inducement by way of fraud or threat, then it becomes voidable. ${ }^{24} \mathrm{Khul}^{\prime} i$ is similar to Mubarak but with slight difference. The former is initiated by the wife and not by both of them while Mubarak is a separation by mutual agreement of the parties..$^{25}$

The consideration for Khul'i has to be something lawful i.e. whatever is lawful to be accepted as dowry then it should also be a lawful consideration for Khul'i and the consideration has to be specified by the spouses. ${ }^{26}$ The time for the payment of the consideration has to be specified either immediately or at an agreed time, and where no period has been fixed, then it has to be paid immediately when the Khul'i is pronounced. ${ }^{27}$

According to Hannafi school of thought, as a general rule, the amount to be paid by the wife as consideration should not exceed the amount of the wife's dowry or property given by the husband. ${ }^{28}$ And where the consideration exceeded the dowry, it is valid but disapproved. They based their argument on the hadith where the wife of the Thabit met the Holy prophet for Khul'i. The wife of habit told the Holy Prophet that she is willing to give more than what she received from her husband while the Holy Prophet said "No, not more than that." 29

However, the Hannafi School holds the view that if a husband divorces his wife by way of Khul'i, and the marriage has not been consummated, the dowry has been paid, then the wife has to return the full dowry. ${ }^{30}$ However, if it has not been paid, then the husband's liability to pay has ceased. While under Maliki school of thought, if the marriage has not been consummated and the spouses have agreed on certain consideration, the wife has to pay the agreed consideration and the right to her dowry shall be extinguished, meaning that she is not entitled to get anything from the dowry. ${ }^{31}$

Conversely, Imam Shafi'i is of the view that, where the marriage has not been consummated and the spouses have agreed on specified sum, then the wife is entitled to half of her dowry and if not yet paid, the husband has to pay her half of the dowry. ${ }^{32}$ On the other hand, Imam Hanbali is of the opinion that the right to dower is not lost as a

22 Narrated by al-Bukhari, 5273

23 Lemo, A.B. (1990). Islamic Studies for Senior Secondary Schools Book 2 \& 3. Nigeria: Islamic Education Trust Publication Division, Minna, p. 195.

24 Pearl, D. (1979). A Textbook on Muslim Law, London: Croom Helm Ltd, p. 102.

25 Kamali, M.H. (2000). Islamic Law in Malaysia. Kuala Lumpur: Ilmiah Publisher, p. 77.

26 Ibrahim, A. (1972). Op.Cit., pp. 260-261.

27 Ibid., p. 262.

28 Ibid.

29 Al-Bayhaqi, Al-Sunan Al-Kubra, Hyderabad, Deccan, 1353 A.H vol. II p.314 as cited in Ibrahim, A. (1972). Ibid.,p. 263.

$30 \quad$ Ibid., p. 267.

31 Ibid., p. 268

32 Ibid., p. 268. 
result of Khul' $i$ and the husband is liable to pay if it has not been paid. Other rights like maintenance during Iddah is not lost on the pronouncement of Khul'i because it arises only after the divorce or Khul'i has been pronounced, unless it is part of the agreement during the Khul'i.

\section{Laws and Practices of Khul'i in Different Muslims' Countries}

This section contains a brief discussion on laws and practices of Khu'il in different Muslims' countries such as Malaysia, Libya and Pakistan with a view to have a benchmark and good practice that is in line with the Islamic doctrines.

\subsection{Malaysia}

Under the Malaysian Islamic Family Law, Khul'i is regarded as one of the types of divorce that is made by mutual consent. Section 49(1) of Islamic Family Law of Malaysia ${ }^{33}$ provides that where a husband is not willing to freely divorce his wife but the couples agreed that the husband shall pronounce divorce upon received of his dowry or something from the wife, and if such happens, it is a divorce by way of Khul'i. The section further provides that a court after the couples have agreed about the amount to pay, cause the husband to pronounce divorce which is irreversible. And where the couples have not agreed about how much or what to pay by the wife, the Islamic court is empowered by the law to assess and determine what or how much to pay by the wife in accordance with the Islamic law taking into account the status and means of the parties as provided under section 49(2) of Islamic Family Law.

\subsection{Libya}

Article 28 of the Libyan Family Law provides that in all cases, a divorce shall not be recognized except by a declaration by the relevant court and a wife may also obtain Khul'i from her husband by giving him appropriate compensation, which may include postponed dowry or custody over children. ${ }^{34}$ It also provides that if the husband retracts the offer of Khul'i due to stubbornness, court is authorized to rule on the offer and directed the wife to return or give him appropriate compensation.

\subsection{Pakistan}

Under the Pakistan Family Law, there is no specific provision regulating Khul' $i$, but it is dealt under the Dissolution of Muslim Marriages Act of 1939 of Pakistan. ${ }^{35}$ The Act under Article 2(ix), a woman married in accordance with the Islamic Law shall be allowed to obtain a decree for the dissolution of her marriage on any other ground which is accepted as lawful for the dissolution of marriage under Islamic Law. In practice, however, where the wife is unhappy with her husband, she can file an application for Khul' $i$ in court and the husband has the period of six months within which to appear before the court. ${ }^{36}$ And in the event he failed or refused to appear, the judge will pronounce the divorce on his behalf.

Some scholars like Mehmood and Farooq criticize the pronouncement of Talaq by the judge on behalf of the husband as provided under the Pakistan law. This is because

33 Federal Territory, Act 303 of 1984.

34 Libyan Family Law (Law no 10 of 1984)

35 Mehmood, M.I., and Farooq, S. (2014). "Khul'(Redemption) in Islamic Law and Its Practice in Pakistani Courts: A Legal Critical Analysis, Mediterranean Journal of Social Sciences MCSER Publishing, Rome-Italy, 5(3), p. 296.

36 Ibid. 
according to them, it is only the husband that has the right to pronounce divorce to his wife. Nevertheless, one should consider the case that was brought before Caliph Umar (may Allah be pleased with him), where a woman wanted to give her husband Khul'i but Caliph Umar advised her to be patient. And she insisted even after he put her in a prison and according to her that was the only night she slept peacefully. Therefore, Caliph Umar ordered her husband to divorce her and this according to Maudodi, the judge has an authority to force or pronounce a divorce on behalf of the husband based on Khul'i. ${ }^{37}$ Another justification, Usmani states in his study that Ibn Rushd inscribes that divorce is the right of man and the Khul' $i$ is the right of a female, and if the husband hates his wife, he can pronounce divorce and if the wife hates her husband, she has the right of Khul'i.38

\section{Khul'i under Shari'a Courts New Rules, 2013}

The Grand Khadi of Bauchi State is empowered under section 7(ii) of the Shari'a Courts Law, 2001 of Bauchi State, Nigeria to make rules to regulate all the proceedings before Shari' a Courts in the State. Based on the above provision, the Grand Khadi of Bauchi State signed the Bauchi State Shari' a Courts Civil Procedure (Amendment) Rules, 2013 on the $2^{\text {nd }}$ day of October, 2013. The new rules is a momentous achievement because it brought a lot of modifications which among others include; a provision on prescription (Hauzi), Redemption (Khul'i), Custody of Children, Maintenance (Annafaqa), Maintenance of a Divorce Wife and others which were not part of the old rules.

However, based on the above development, Order 21 of the New Shari' a Courts Rules, 2013 provides the right of redemption to the wife by giving something to her husband to get a divorce. Order 21 provides as follows:

a) A wife can redeem herself from the bond of marriage by:-

i. Returning the full dowry or

ii. Maintenance of pregnancy or

iii. Maintenance of self during Iddah period or

iv. Maintenance of her child

b) If a wife opts for redemption by maintenance of her child and the child died, the father will not be entitled to anything for the remaining period of the maintenance.

From the wordings of Order 21, Rule 1, there are 4 ways upon which a wife can redeem herself from marriage. Firstly, by returning the dowry, a husband can relieve his wife from the bond of marriage by way of redemption (Khul'i) after she paid him back his full dowry given to her at the time of contracting the marriage. Secondly, she may also redeem her herself from the bond of marriage, if she agrees to maintain her pregnancy up to the time that she will deliver. Thirdly, is by way of maintaining herself during Iddah period. Her maintenance during pregnancy and Iddah period include feeding, shelter, medication and other daily needs. That is to say, she will not request anything from the husband for her maintenance.

Last but not least, by way of maintaining her child for a certain period. Rule 2 went further to state in the event the wife decided to maintain her child for a certain period of time, in the process or after she has started taking care of her child by providing food, shelter and other daily needs and the child died, then the husband is not entitle to

37 Maudodi. A.A. (2010). Huqooq-uz-Zavjan. Lahore: Idara Tarjumanul Quran Private limited.

38 M. T. Usmani. (2001). "Islam ma Khul' ki haqiqat" as cited in Mehmood, M.I., and Farooq, S. (2014). Op.Cit., p. 296. 
anything for the remaining period of maintenance. Further, with respect to the quantum of compensation, Order 21 Rule 3 provides that a wife can give her husband anything she deems fit as Khul'i to her husband to release her from the bond of marriage.

\section{The Issues and Challenges on Khul'i under the Shari'a Court New Rules, 2013}

As clearly stated above, there is no doubt that the enactment of New Shari'a Courts Rules, 2013 is a welcome development because the new rules incorporated so many issues that were not part of the old rules. Despite the said development, there are some issues that need to be incorporated and to be part of the new rules. These issues are discussed below.

First and foremost, one may argue that Order 21 Rule 1(i) of the New Shari'a Courts Rules, 2013 which provides that a wife can redeem herself from the bond of marriage by returning the full dowry to her husband is in conflict with Order 21 Rule 3 which states that a wife can give her husband anything she deems fit as Khul'i. By interpreting Rule 3 , it can be argued that a wife can give a compensation or consideration to her husband any amount or anything she feels like in order to get divorce from him and the husband cannot challenge the consideration, considering that is the position of the law under the New Shari'a Courts Rules, 2013. More so, Order 21, Rule 3 of the New Shari'a Courts Rules, 2013 is inconsistency with the decision of the court in the case of Kande Inusa $v$. Inusa Manga, ${ }^{39}$ where the court held that once the issue of Khul'i has been presented before the court, the consideration demanded by the husband before divorcing his wife becomes a matter of arrangement and negotiation between the husband and the wife.

Secondly, Order 21 Rule 1(i) of the New Shari'a Courts Rules, 2013 provides that a wife can redeem herself from the bond of marriage by returning the full dowry to her husband. A situation may arise after the marriage has been contracted but before consummation, the wife may decide to get a divorce from the husband for one reason or the other by way of Khul'i. At this point, the researchers argue that it is not fair and just for the husband to only receive his dowry from the wife without getting back the clothes and other things he bought for the wife before contracting the marriage. This is because nowadays, it is part of the custom that a husband has to buy clothes and other things that the wife should wear in his house. And since the wife is yet to use the clothes bought for her, it is not wise and proper for her to retain them due to fact that the husband bought them for her to wear or use them in his house and not in their house or somewhere else.

At this junction, it is of great importance to distinguish the above scenario with the case of Khul'i during the lifetime of the Holy Prophet where the wife of Thaabit requested for a divorce from her husband in return for his dowry. During the lifetime of the Holy Prophet, it is not part of the marriage requirements for the husband to buy clothes and other things for the wife before the marriage. Nonetheless, it is almost compulsory these days for a husband to buy such clothes. In the event he refused, it will become a problem to the extent that the family of the wife may even refuse to give her marriage due to that failure. Another issue regarding the case of the wife of Thaabit is that, the wife was living with her husband before she brought the complaint to the Holy Prophet. While in respect of the above scenario, the wife has not yet relocated to the husband's house.

39 (2013) SQLR (PART IV), Ratio 5. 
Hence, if we stick to the position of the New Shari'a Courts Rules 2013, it will be detrimental to the society because some women may use it as an avenue for enriching themselves. After contracting the marriage but before consummation, may request for $K h u l ' i$. Since they will only pay back the dowry or anything they deem fit without the clothes and other gifts bought to them by their husbands. In this respect, it is of paramount to share the view of the Hammudah where stated that, if a wife is not happy with her husband on her personal reason(s) and the husband is not at fault in any way, she can seek a divorce by way of Khul'i and return to him the dowry and other marriage gifts so as to compensate for his sensible and other losses. ${ }^{40}$

In addition, the consensus reached by the 62 Islamic scholars, jurists and academicians at a validation meeting held in Dutse, Jigawa State, Nigeria will be of great importance in addressing the above problem. The scholars resolved that Khul'i will be limited to dowry paid by the husband, but where the husband paid the dowry above the normal amount prescribed by Shari'a, then it is for the judge to decide what is affordable and reasonable for the wife to pay. ${ }^{41}$ The positon of the scholars above is also consistent with the decision of the court in the case of Kande Inusa v. Inusa Manga,42 where the court held that a wife is permitted to ransom herself by giving to her husband the exact dowry paid or a lesser amount or more than the amount of dowry paid.

Under the New Shari'a Courts Rules 2013, it is silence as to the duration of the waiting period (Iddah) after Khul'i. It is same as an ordinary divorce by the husband i.e. three (3) menstrual courses, it is count as a single divorce but the husband cannot taker the wife back without her consent and a fresh marriage as rightly stated by Lemo. ${ }^{33}$ Similarly, the New Shari'a Courts Rules 2013 has not prescribed the time within which the payment of the consideration should be made. Is it immediately or at an agreed time and what will be the position where no period has been fixed between the spouses?

\section{Conclusion}

From the discussion above, it is evidently clear that there are some issues that need to be addressed under the Sharia Courts New Rules 2013. It is recommended that the conflicting provisions should be amended in order to clear that ambiguity. The amendment should clearly state that once the issue of Khul'i is brought before the court, it should be a matter of arrangement and negotiation between the parties as rightly held in the case of Kande Inusa $v$. Inusa Manga discussed above. It should also take into account of a situation where the marriage has not been consummated and the wife is yet to relocate to her husband house, to return his full dowry and other gifts to him before divorcing her. This will go a long way in blocking an avenue for women to enrich themselves from keeping the marriage gifts with them, in the event of being divorced by way of Khul'i.

The Rules should equally make it unequivocally clear that the duration of the waiting period (Iddah) for the Khul'i is three (3) months, the husband cannot take her back without her consent and without conducting another marriage. This is because some people may out of ignorance or selfish interest decide to take her back just as in divorce made at his instance. And lastly, the rules should be specific as to the time for the

40 Hammudah Abd al Ati, The Family Structure in Islam Available online at http://d1.islamhouse.com/data/en /ih_books/single/en_Family_Structure_in_Islam.pdf accessed December 15, 2015.

41 Al-Amin Ciroma. (2009). Al-Khul': The Woman's Choice, p. 1.

42 (2013) SQLR (PART IV), Ratio 5.

43 Lemo, A.B. (1990). Op. Cit., p. 195. 
payment of consideration for the Khul'i which either should be immediately or at a specified time and in the event the parties have not reached a consensus as to the time, then it should be decided by the court.

\section{References}

Abdu M.O.A. (1978). Islam as a Religion (Faith and Duties). Nigeria: Islamic Publications Bureau, Lagos.

Abikan, A.Q.I. (2002). "The Application of Islamic Law in Civil Causes in Nigerian Courts," Journal of International and Comparative Law, 6, 88-115.

Ajijola, A.A.D. (1989). Introduction to Islamic Law. New Delhi: International Islamic Publishers.

Al-Bayhaqi, Al-Sunan Al-Kubra, Hyderabad, Deccan, 1353 A.H vol. II

Al-fatawa al -Hindiyah Knapur, 1349 A.H Vol. II

Amara, R.B. (2011). The Izala Movement in Nigeria: It's Spilt, Relationship to Sufis and Perception of Shari'a Re-Implementation. PhD Thesis, Bayreuth International Graduate School of African Studies.

Ciroma, A. (2009). Al-Khul': The Woman's Choice. Available online at http://al-aminciroma.blogspot.my/2009/10/al-khul-womans-choice.html accessed November 6, 2015.

Doi, A.R.I. (1997). Sharia the Islamic Law. London: Ta Ha Publishers.

Family Law of Malaysia (Federal Territory) Act 303 of 1984.

Hammudah Abd al Ati, The Family Structure in Islam Available online at http://d1.islamhouse.com/data/en/ih_books/single/en_Family_Structure_in_Islam.pdf accessed December 15, 2015.

Ibn Abidin al-Shami, Radda al -Muhtar, Cairo, 1318 A.H, Vol. II

Ibn Qudamah al-Mughni, Cairo 130 A.H Vol. II

Ibrahim, A. (1972). Islamic Law in Malaya. Singapore: Malaysian Sociological Research Institute Ltd.

Jonathan, R. (2001). "Good and Bad Muslims: Islam and Indirect Rule in the Northern Nigeria," International Journal of African Historical Studies, 3(4), 601-618.

Kamali, M.H. (2000). Islamic Law in Malaysia. Kuala Lumpur: Ilmiah Publisher.

Kande Inusa v. Inusa Manga (2013) SQLR (PART IV).

Lemo, A.B. (1990). Islamic Studies for Senior Secondary Schools Book 2 E 3. Nigeria: Islamic Education Trust Publication Division, Minna.

Libyan Family Law (Law no 10 of 1984)

Maudodi. A.A. (2010). Huqooq-uz-Zavjan. Lahore: Idara Tarjumanul Quran Private limited.

Mehmood, M.I., and Farooq, S. (2014). "Khul'(Redemption) in Islamic Law and Its Practice in Pakistani Courts: A Legal Critical Analysis, Mediterranean Journal of Social Sciences MCSER Publishing, Rome-Italy, 5(3). 290-297. 
P-ISSN: 2442-9880, E-ISSN: 2442-9899

Oduyoye. M. (2000). The Sharia Debate in Nigeria: October 1999-October 2000. Ibadan. Pearl, D. (1979). A Textbook on Muslim Law, London: Croom Helm Ltd. 